\title{
Salmonella Serotype Group C
}

National Cancer Institute

\section{Source}

National Cancer Institute. Salmonella Serotype Group C. NCI Thesaurus. Code C124381.

Characterization of salmonella bacteria subspecies as serotype group $\mathrm{C}$ based on the specific immunologic reactivity of cell surface lipopolysaccharide-protein chains called $O$ antigens. 